\title{
Optimization of Early Steps in Oncolytic Adenovirus ONCOS-401 Production in T-175 and HYPERFlasks
}

\author{
Lukasz Kuryk ${ }^{1,2,3, *(0)}$, Anne-Sophie W Moller ${ }^{4}$, Antti Vuolanto ${ }^{5, \dagger}$, Sari Pesonen ${ }^{6, \ddagger}$, \\ Mariangela Garofalo ${ }^{3,7}$, Vincenzo Cerullo $^{3}$ and Magnus Jaderberg ${ }^{4}$ \\ 1 Targovax Oy, Clinical Science, 00180 Helsinki, Finland \\ 2 National Institute of Public Health-National Institute of Hygiene, Department of Virology, \\ 00-0791 Warsaw, Poland \\ 3 Drug Research Program, ImmunoVirothearpy Lab, Faculty of Pharmacy, University of Helsinki, \\ 00014 Helsinki, Finland; mariangela.garofalo@unimi.it (M.G.); vincenzo.cerullo@helsinki.fi (V.C.) \\ 4 Targovax ASA, Clinical Science, 0283 Oslo, Norway; anne-sophie.moller@targovax.com (A.-S.W.M.); \\ magnus.jaderberg@targovax.com (M.J.) \\ 5 Targovax Oy, CMC, 00180 Helsinki, Finland; antti.vuolanto@gmail.com \\ 6 Targovax Oy, R\&D, 00180 Helsinki, Finland; sari.pesonen@valotx.com \\ 7 Department of Oncology and Hemato-Oncology, Center of Excellence on Neurodegenerative Diseases, \\ University of Milan, 20133 Milan, Italy \\ * Correspondence: lukasz.kuryk@targovax.com; Tel.: +358-504-683-608 \\ + Current address: Herantis Pharma Plc, 02600 Espoo, Finland. \\ $\ddagger$ Current address: Valo Therapeutics Ltd., 00100 Helsinki, Finland.
}

Received: 20 December 2018; Accepted: 29 January 2019; Published: 31 January 2019

\begin{abstract}
Oncolytic adenoviruses can trigger lysis of tumor cells, induce an antitumor immune response, bypass classical chemotherapeutic resistance strategies of tumors, and provide opportunities for combination strategies. A major challenge is the development of scalable production methods for viral seed stocks and sufficient quantities of clinical grade viruses. Because of promising clinical signals in a compassionate use program (Advanced Therapy Access Program) which supported further development, we chose the oncolytic adenovirus ONCOS-401 as a testbed for a new approach to scale up. We found that the best viral production conditions in both T-175 flasks and HYPERFlasks included A549 cells grown to 220,000 cells $/ \mathrm{cm}^{2}$ ( $80 \%$ confluency), with ONCOS-401 infection at 30 multiplicity of infection (MOI), and an incubation period of $66 \mathrm{~h}$. The Lysis A harvesting method with benzonase provided the highest viral yield from both T-175 and HYPERFlasks $(10,887 \pm 100$ and 14,559 \pm 802 infectious viral particles/cell, respectively). T-175 flasks and HYPERFlasks produced up to $2.1 \times 10^{9} \pm 0.2$ and $1.75 \times 10^{9} \pm 0.08$ infectious particles of ONCOS-401 per $\mathrm{cm}^{2}$ of surface area, respectively. Our findings suggest a suitable stepwise process that can be applied to optimizing the initial production of other oncolytic viruses.
\end{abstract}

Keywords: oncolytic adenovirus; CD40L; productivity; benzonase; manufacturing; optimization; cancer; MOI; harvesting time; virus productivity

\section{Introduction}

Oncolytic viruses (OVs) selectively replicate and lyse cancer cells; spreading within the tumor mass; circulating into distant metastases; and not significantly harming normal cells. OVs can exhibit natural tumor-selective tropism (reovirus) [1] or be genetically modified for cancer cell-restricted replication (adenovirus; poliovirus; herpes simplex; vaccinia; Newcastle disease virus; measles) [2,3].

Oncolytic adenoviruses constitute a class of biologics that can trigger lysis of tumor cells, release damage-associated molecular patterns (DAMPs), which help induce an antitumor immune response, 
circumvent classical chemotherapeutic resistance strategies of tumors, and provide opportunities for combination strategies [4-18]. Oncolytic adenoviruses often have a mutated or deleted E1A gene, which is required for adenoviral replication. E1A proteins are responsible for dissociation of the retinoblastoma $(\mathrm{Rb}) / \mathrm{E} 2 \mathrm{~F}$ proteins, resulting in activation of free transcription factor E2F. Many of the commonly investigated oncolytic adenoviruses have a $24 \mathrm{bp}$ deletion in the $E 1 A$ gene $(\Delta 24)$, which disrupts the retinoblastoma $(\mathrm{Rb})$ binding domain, arresting virus replication [8].

In addition, oncolytic adenoviruses can augment or broaden the immune response by expressing a transgene with inflammatory or immune stimulatory properties, such as granulocyte-macrophage colony-stimulating factor (GM-CSF) [19,20], CD40L [4,21-25], and IL-12 and IL-18 [26]. Adenovirus 5 was the most commonly explored serotype, but its receptor (CAR) is downregulated in many tumor types and it has a strong tropism for the liver which sequesters most of the intravenously (i.v.) administered dose. Many oncolytic adenoviruses incorporate chimeric fiber knobs so they have altered specificity by utilizing receptors for alternate serotypes $[8,19,22,23,27]$. In comparison to Ad5 vectors, oncolytic Ad with an RGD motif interacts more efficiently with the integrins expressed on ovarian and prostate cancers and gliomas [5]. Oncolytic Ad with a chimeric Ad3 fiber knob interacts more efficiently with desmoglein (DSG), which is overexpressed in many epithelial cancers [28,29].

Like all adenoviruses [30], one of the major challenges of moving targeted adenoviruses through clinical trials is the development of scalable production methods for generating viral seed stocks and sufficient quantities of clinical grade viruses in a suitable formulation [11]. We chose to use the oncolytic adenovirus ONCOS-401 as a model because its intratumoral administration into progressing advanced solid tumors in nine patients in a regulated Advanced Therapy Access Program (ISRCTN10141600) showed disease control in $83 \%$ of the evaluable patients [22]. ONCOS- 401 is an oncolytic adenovirus with three modifications [23]. First, its E1A gene is driven by the human telomerase (hTERT) promoter [23], which is commonly overexpressed in many tumors. Second, ONCOS-401 features an Ad5/3 chimeric fiber knob, which can bind and infect cells that express the desmoglein [28]. Third, ONCOS-401 expresses CD40L, which can augment the induction of antitumor responses [31].

Optimization studies of oncolytic adenoviral production processes are essential to enhance and maximize virus productivity and to set conditions for upscaling the purification process, which can provide sufficient yields for clinical studies and the market. Optimization of the manufacturing process of Ad often includes evaluation of the type, confluency, and growth conditions of the host cell line; variation of multiplicity of infection; assessment of optimal harvesting time and initial harvesting method with cell disruption; often treatment with benzonase ${ }^{\mathrm{TM}}$ to digest DNA and RNA; and passage through one or more chromatographic columns such as anion exchange, gel infiltration, size exclusion column; and formulation that fosters long-term stability [11].

The purpose of these studies was to optimize the initial steps: conditions for ONCOS-401 production in A549 cells and the initial harvesting processes. Both the growth parameters and the harvesting methods can affect the viral yield. Maximizing the viral production at these initial steps can improve the overall yield after purification. Here, we compared yields for the ONCOS-401 replication and production in T-175 flasks and HYPERFlask flasks, which were used as a scaled-down model for a bioreactor. Although A549 cells do not contain any adenoviral E1 sequences like HEK293 cells, A549 cells support ONCOS-401 replication [32]. Thus, we eliminated the possibility of E1A recombination and generation of E1 wildtype viruses in our stocks by choosing the A549 lung cancer line as the host cell. Modifying the protocols from the T-175 flasks to HYPERFlasks provided a model for scaling up the production. In addition, we compared the viral production by five related harvesting methods. Studies were concentrated on optimization of the multiplicity of infection (MOI), the duration of the incubation period before harvesting, and the initial harvesting method. Comparisons include not only total viral particles from batch but also viral productivity (infectious viral particles/cell and infectious viruses per $\mathrm{cm}^{2}$ ). Optimizing the viral yield in the initial steps provides the necessary foundation for efficient elucidation of the purification methods. 


\section{Results}

The two main purposes of these studies were to optimize the harvested viral production for ONCOS-401 in a T-175 and in HYPERFlasks. Cells incubated for $96 \mathrm{~h}$ in T-175 or $144 \mathrm{~h}$ in HYPERFlask were in a logarithmic phase of growth, almost reaching the maximum of their possible growth. Based on growth curves, cell density at the time for infection $\left(80 \%\right.$ confluent) was $220,000 \mathrm{cells} / \mathrm{cm}^{2}$.

\subsection{Effect of Harvesting Time After Infection with MOI of 10}

Three studies (1-3) were performed in T-175 flasks (cell binding surface) to determine the harvesting time (range: 48-96 h) (Figures 1 and 2) that yielded the highest ONCOS-401 viral production (Table 1). The Lysis A harvesting method was performed. The full CPE was observed at $72 \mathrm{~h}$ post infection. However, this time point did not result in the highest viral productivity. The three experiments indicated that A549 cells inoculated with a MOI of 10 provided the highest titer at 60 and $66 \mathrm{~h}$ (Figures 1 and 2). Thus, the harvest time of $66 \mathrm{~h}$ post ONCOS-401 infection was chosen for subsequent experiments.

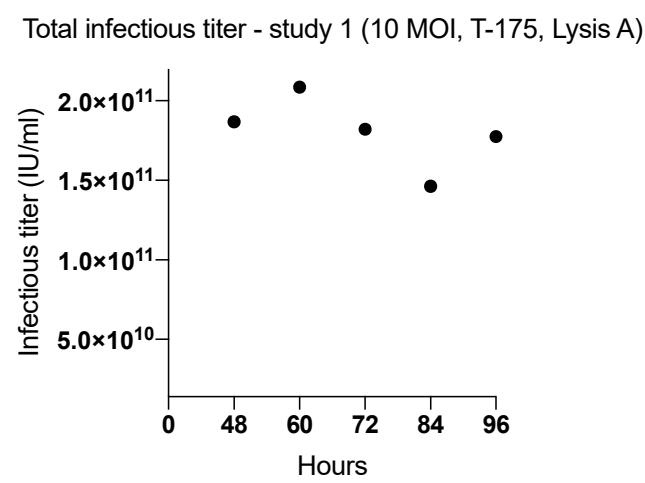

Figure 1. The effect of length of incubation period of ONCOS-401 infected A549 cells (MOI = 10) on the yield of infectious viral particles in T-175 flasks. The infectious titers were tested at harvesting times of $48,60,72,84$ and $96 \mathrm{~h}$. The highest viral titers were obtained at $60 \mathrm{~h}$ post infection. Values are presented as means.

(a)

Total infectious titer - study 2 (10 MOI, T-175, Lysis A)

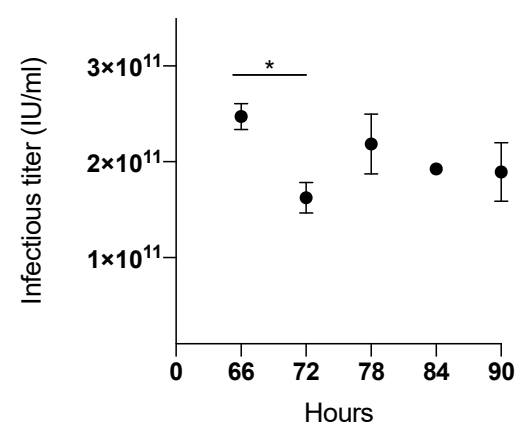

(b)

Total infectious titer - study 3 (10 MOI, T-175, Lysis A)

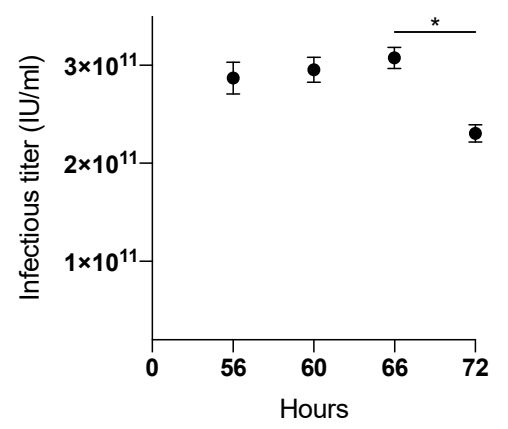

Figure 2. The effect of length of incubation period of ONCOS-401 infected A549 cells $(\mathrm{MOI}=10)$ on the yield of infectious viral particles in T-175 flasks. (a) The infectious titers from ONCOS-401 infected A549 cells $(\mathrm{MOI}=10)$ in T-175 flasks were tested at harvesting times of $66,72,78,84,90 \mathrm{~h}$ : the highest viral titers were obtained at $66 \mathrm{~h}$ post infection. (b) The effect of length of incubation period of ONCOS-401 infected A549 cells (MOI = 10) on the yield of infectious viral particles in T-175 flasks. The yield of infectious viral particles from ONCOS-401 infected A549 cells in T-175 flasks were tested at harvesting times of 56, 60, 66, $72 \mathrm{~h}$ : similar titers were obtained at harvest times of 56 to $66 \mathrm{~h}$ post infection. Values are presented as means $\pm \mathrm{SD},{ }^{*} p<0.05$. 
Table 1. Virus Productivity.

\begin{tabular}{|c|c|c|c|c|c|}
\hline $\begin{array}{l}\text { Optimization } \\
\text { Study (Number) }\end{array}$ & $\begin{array}{l}\text { Harvesting } \\
\text { Time (h) }\end{array}$ & MOI & Harvesting Method & $\begin{array}{l}\text { Total Virus } \\
\text { Particles (IU), } \\
\text { (Mean) }\end{array}$ & $\begin{array}{l}\text { Virus Productivity } \\
\text { (Number of Virus } \\
\text { Particles/Cell), (Mean) }\end{array}$ \\
\hline \multirow{5}{*}{$1(\mathrm{~T}-175)$} & 48 & \multirow{5}{*}{10} & \multirow{5}{*}{ Lysis A } & $1.86 \times 10^{11}$ & 5576 \\
\hline & 60 & & & $2.08 \times 10^{11}$ & 6226 \\
\hline & 72 & & & $1.82 \times 10^{11}$ & 5438 \\
\hline & 84 & & & $1.46 \times 10^{11}$ & 4365 \\
\hline & 96 & & & $1.77 \times 10^{11}$ & 5299 \\
\hline \multirow{5}{*}{$2(\mathrm{~T}-175)$} & 66 & \multirow{5}{*}{10} & \multirow{5}{*}{ Lysis A } & $2.47 \times 10^{11}$ & 6682 \\
\hline & 72 & & & $1.63 \times 10^{11}$ & 3779 \\
\hline & 78 & & & $2.19 \times 10^{11}$ & 5083 \\
\hline & 84 & & & $1.92 \times 10^{11}$ & 4476 \\
\hline & 90 & & & $1.90 \times 10^{11}$ & 5124 \\
\hline \multirow{4}{*}{$3(\mathrm{~T}-175)$} & 56 & \multirow{4}{*}{10} & \multirow{4}{*}{ Lysis A } & $2.87 \times 10^{11}$ & 7966 \\
\hline & 60 & & & $2.95 \times 10^{11}$ & 8205 \\
\hline & 66 & & & $3.07 \times 10^{11}$ & 8538 \\
\hline & 72 & & & $2.30 \times 10^{11}$ & 6401 \\
\hline \multirow{5}{*}{4 (T-175) } & \multirow{5}{*}{66} & 1 & \multirow{5}{*}{ Lysis A } & $6.39 \times 10^{10}$ & 1494 \\
\hline & & 5 & & $2.17 \times 10^{11}$ & 5085 \\
\hline & & 20 & & $3.06 \times 10^{11}$ & 7153 \\
\hline & & 50 & & $3.30 \times 10^{11}$ & 7715 \\
\hline & & 100 & & $1.85 \times 10^{11}$ & 4338 \\
\hline 5 (HYPERFlask) & 66 & \multirow{5}{*}{30} & Lysis A & $3.02 \times 10^{12}$ & 14,559 \\
\hline \multirow{4}{*}{6 (HYPERFlask) } & 60 & & \multirow{4}{*}{ TrypLE } & $8.51 \times 10^{11}$ & 2497 \\
\hline & 66 & & & $6.96 \times 10^{11}$ & 2044 \\
\hline & 72 & & & $7.40 \times 10^{11}$ & 2172 \\
\hline & 96 & & & $8.43 \times 10^{11}$ & 2475 \\
\hline \multirow{7}{*}{$\begin{array}{c}7 \text { (T-175 \& } \\
\text { HYPERFlask) }\end{array}$} & \multirow{7}{*}{66} & \multirow{7}{*}{30} & $\begin{array}{l}\text { Lysis A } \\
\text { T-175 }\end{array}$ & $3.72 \times 10^{11}$ & 10,887 \\
\hline & & & $\begin{array}{l}\text { Lysis B } \\
\text { T-175 }\end{array}$ & $1.48 \times 10^{11}$ & 4331 \\
\hline & & & $\begin{array}{l}\text { Lysis C } \\
\text { T-175 }\end{array}$ & $1.96 \times 10^{11}$ & 5741 \\
\hline & & & $\begin{array}{c}\text { Lysis D } \\
\text { HYPERFlask }\end{array}$ & $4.36 \times 10^{11}$ & 1279 \\
\hline & & & $\begin{array}{c}\text { Lysis C } \\
\text { HYPERFlask }\end{array}$ & $8.09 \times 10^{11}$ & 2374 \\
\hline & & & $\begin{array}{c}\begin{array}{c}\text { Benzonase treatment } \\
\text { (pellet 1) } \\
\text { HYPERFlask }\end{array} \\
\end{array}$ & $4.35 \times 10^{11}$ & 1275 \\
\hline & & & $\begin{array}{c}\text { Benzonase treatment } \\
\text { (pellet 2) } \\
\text { HYPERFlask }\end{array}$ & $1.08 \times 10^{11}$ & 315 \\
\hline
\end{tabular}

\subsection{Effect of Inoculum Size on Quantity of Harvested Viruses}

Comparison of ONCOS-401 yields from T-175 flasks infected with various MOIs indicated a clear dependence of viral productivity on the MOI of the inoculum. Cells infected with $20 \mathrm{MOI}$ or $50 \mathrm{MOI}$ in T-175 flasks followed by the Lysis A harvesting method yielded the highest quantity of harvested virus (Figure 3), $3.06 \times 10^{11}$ and $3.30 \times 10^{11} \mathrm{IU}$ respectively. We chose an intermediate MOI, i.e., $30 \mathrm{MOI}$, 
for further studies in HYPERFlasks on the production process. We assessed the quantity of harvested ONCOS-401 virus from 3 HYPERFlasks inoculated with a MOI of 30 after $66 \mathrm{~h}$ and harvested by the Lysis A method in study 5: the mean viral productivity for the three HYPERFlasks was 14,559 \pm 802 viruses per cell (Table 1).

Because the inoculum size $(\mathrm{MOI}=30)$ was different from the inoculum in the earlier kinetic experiments, we compared the quantity of harvested virus from cells infected at MOI 30 and incubated in HYPERFlasks at 60, 66, 72, and $96 \mathrm{~h}$ incubation time post infection (Figure 4). To theoretically increase the harvest of viral particles from the HYPERFlask, we used the TrypLE harvesting method (Table 2). The viral yields ranged from $2044 \pm 189$ to $2497 \pm 60$ infectious viral particles/cell. These yields harvested with the TrypLE method were substantially lower than the viral yields from HYPERFlasks obtained with the Lysis A method in study 5 (14,559 \pm 802 infectious viral particles/cell) and $3.02 \times 10^{12} \pm 0.135 \times 10^{12}$ IU per HYPERFlask.

Total infectious titer - study 4 (66 hrs, T-175, Lysis A)

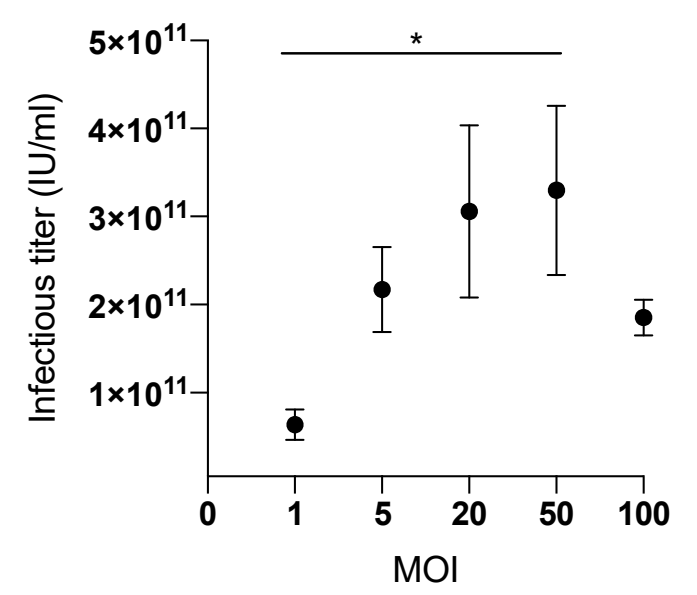

Figure 3. The effect of the input inoculum (MOI) on the yield of infectious viral particles from ONCOS-401 infected A549 cells was determined in T-175 flasks. A549 cells were infected with ONCOS-401 at the indicated MOIs (1, 5, 20, 50 and 100), and the viral particles were harvested at $66 \mathrm{~h}$ post infection. Infectious titers were determined by ICC. The A549 cells infected with 20 and 50 MOI provided the highest viral titers. Moreover, one log drop of titer was observed at 1 MOI. Values are presented as means $\pm \mathrm{SD},{ }^{*} p<0.05$.

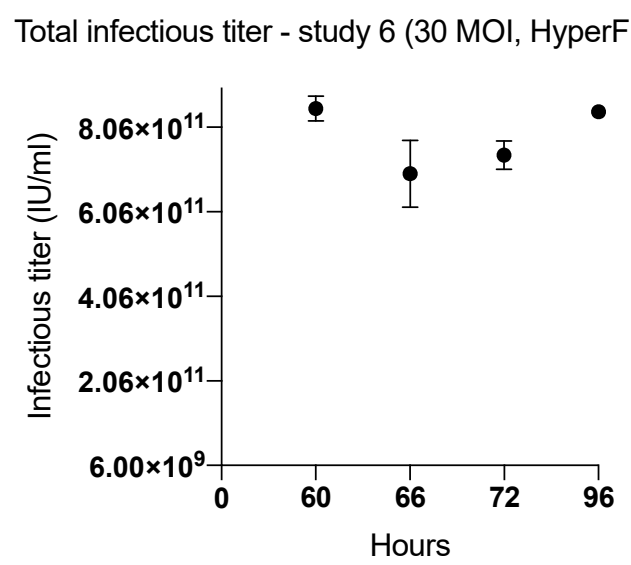

Figure 4. The effect of length of incubation period of ONCOS-401 infected A549 cells $(\mathrm{MOI}=30)$ on the yield of infectious viral particles in HYPERFlasks. ONCOS-401 infected A549 cells (MOI = 30) were incubated in HYPERFlasks for 60, 66, 72, $96 \mathrm{~h}$ and the adenoviral particles were harvested by the TrypLE method. The infectious titers were determined by ICC. The yields of infectious ONCOS-401 viral particles were low compared to previous experiments that used the Lysis A method. 
Table 2. Comparison of the Harvesting Methods.

\begin{tabular}{|c|c|c|c|c|c|}
\hline Steps & Lysis A & TrypLE & Lysis B & Lysis C & Lysis D \\
\hline Collected supernatant & $\mathrm{Y}$ & $\mathrm{Y}$ & Y & Y & $\mathrm{Y}$ \\
\hline $\begin{array}{l}\text { Chemical lysis buffer with } \\
\text { benzonase treatment }(1 \mathrm{~h})\end{array}$ & Y & $\mathrm{N}$ & $\mathrm{N}$ & $\mathrm{N}$ & $\mathrm{N}$ \\
\hline Washes $(1-2 x)$ & $\mathrm{N}$ & Y & Y & Y & $\mathrm{Y}$ \\
\hline TrypLE & $\mathrm{N}$ & $\mathrm{Y}$ & $\mathrm{N}$ & $\mathrm{N}$ & $\mathrm{N}$ \\
\hline $\begin{array}{l}\text { Mechanical disassociation } \\
\text { (firmly tapped 5-10 x) }\end{array}$ & $\mathrm{N}$ & $\mathrm{Y}$ & $\mathrm{Y}$ & $\mathrm{Y}$ & $\mathrm{Y}$ \\
\hline TrypLE & $\mathrm{N}$ & $\mathrm{Y}$ & $\mathrm{N}$ & $\mathrm{N}$ & $\mathrm{N}$ \\
\hline Centrifugation & $\mathrm{N}$ & $1000 \mathrm{rpm}$ & $1000 \mathrm{rpm}$ & $1000 \mathrm{rpm}$ & $1000 \mathrm{rpm}$ \\
\hline $\begin{array}{c}\text { Supernatant removed \& } \\
\text { discarded }\end{array}$ & $\mathrm{N}$ & $\mathrm{Y}$ & $\mathrm{Y}$ & Y & Y \\
\hline $\begin{array}{l}\text { Pellet saved \& resuspended in } \\
\qquad 8-10 \mathrm{~mL}\end{array}$ & $\mathrm{~N}$ & $\mathrm{Y}$ & Y & Y & Y \\
\hline $\begin{array}{c}\text { Chemical lysis buffer with } \\
\text { benzonase } \\
(1 \text { h) on pellet }\end{array}$ & $\mathrm{N}$ & $\mathrm{N}$ & Y & Y & $\mathrm{N}$ \\
\hline $\begin{array}{c}\text { Pipette-based disruption and } \\
\text { homogenization }\end{array}$ & $\mathrm{N}$ & $\mathrm{Y}$ & $\mathrm{Y}$ & Vortexed & Vortexed \\
\hline $\begin{array}{c}\text { Frozen }-80^{\circ} \mathrm{C} \text {, thawed } 3 \mathrm{x} \\
\text { Centrifugation }\end{array}$ & $\begin{array}{c}\mathrm{N} \\
3000 \mathrm{rpm}\end{array}$ & $\begin{array}{c}\mathrm{Y} \\
4000 \mathrm{rpm}\end{array}$ & $\begin{array}{c}\mathrm{Y} \\
4000 \mathrm{rpm}\end{array}$ & $\begin{array}{c}\mathrm{Y} \\
4000 \mathrm{rpm}\end{array}$ & $\begin{array}{c}\mathrm{Y} \\
4000 \mathrm{rpm}\end{array}$ \\
\hline $\begin{array}{c}\text { Supernatant retained, } 5 \% \\
\text { sucrose, \& frozen at }-80^{\circ} \mathrm{C}\end{array}$ & Y & $\mathrm{Y}$ & $\mathrm{Y}$ & $\mathrm{Y}$ & Y \\
\hline Viral titer by ICC & $\mathrm{Y}$ & $Y$ & $Y$ & $Y$ & $Y$ \\
\hline
\end{tabular}

The pooled optimization studies indicate that the highest viral yields occurred with a MOI of 20 or 50, and an incubation period of $66 \mathrm{~h}$ (Figure 5b) for the T-175 flasks, and with a MOI of 30 and an incubation period of $66 \mathrm{~h}$ in the HYPERFlask harvested with Lysis A (Figure 6).

(a)

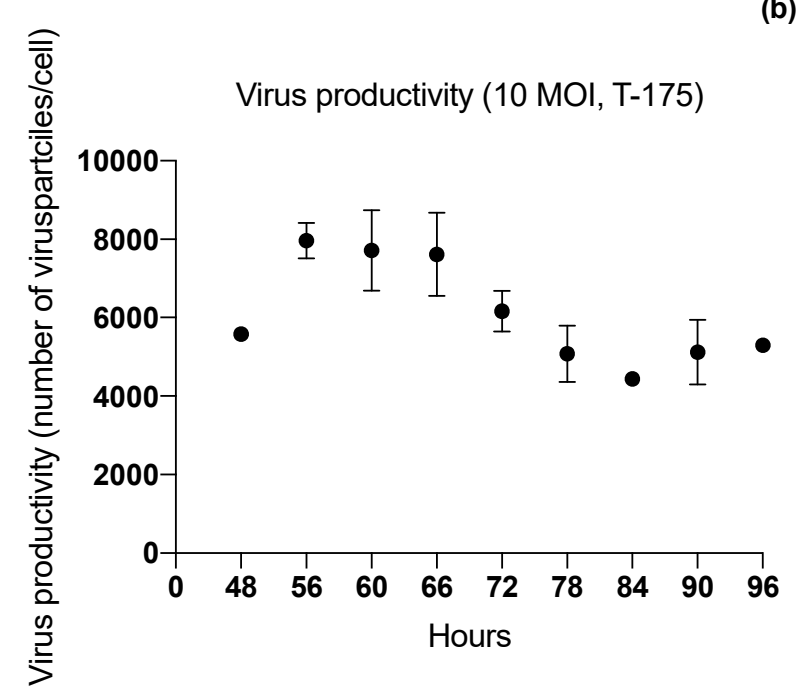

(b)

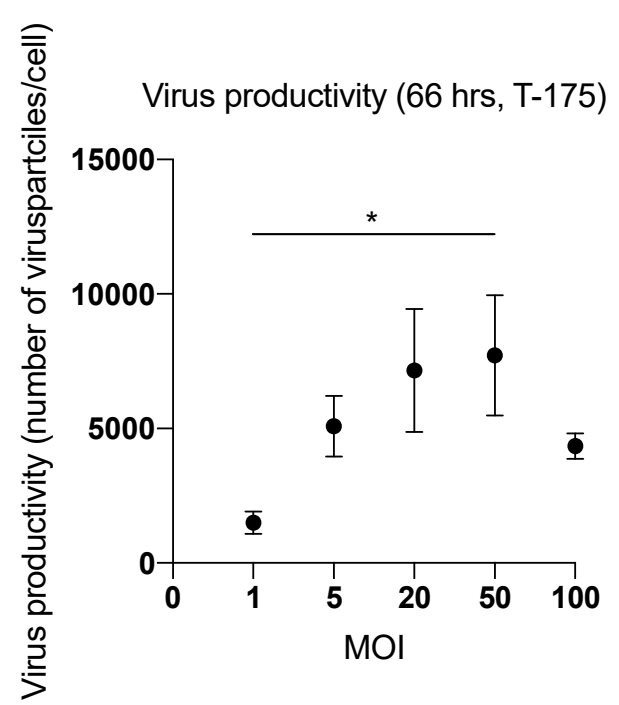

Figure 5. Summary of optimization studies in T-175 flasks. The effect of harvesting time on viral productivity. (a) Virus productivity from ONCOS-401 infected A549 cells (MOI = 10) in T-175. (b) Virus productivity from ONCOS-401 infected A549 cells in T-175 flasks harvested at $66 \mathrm{~h}$. Values are presented as means $\pm \mathrm{SD},{ }^{*} p<0.05$. 


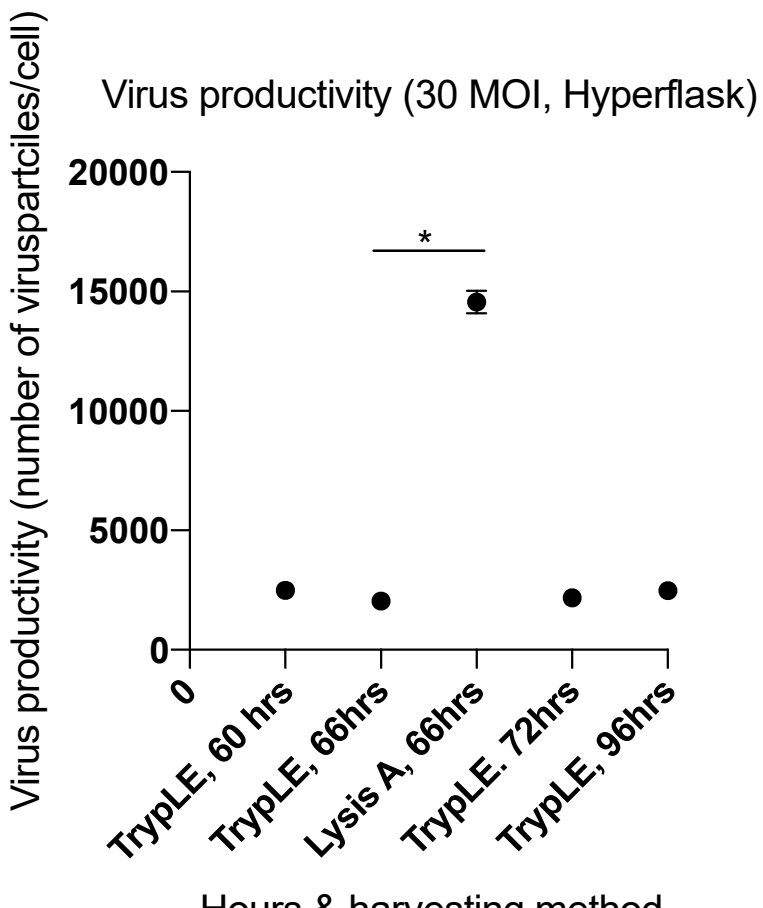

Figure 6. Summary of optimization studies in HYPERFlasks. The effect of harvesting time on total viral infectious titer (IU). Values are presented as means $\pm \mathrm{SD},{ }^{*} p<0.05$.

\subsection{Factors Affecting Yield in the Harvesting Method}

Viral productivity is dependent not only on efficient virus infection and replication but also on the method for harvesting the infected cells and releasing the viruses (Table 2). Since physical disassociation is more challenging in HYPERFlasks, efficient lysis buffers are essential for maximizing viral yield. Lysis buffer allowed collection of a mean harvest for HYPERFlasks in study 5 (MOI of 30; harvesting time $66 \mathrm{~h}$ ) of 14,559 \pm 802 viral particles per cell. Assuming that TrypLE buffer would maintain or augment the harvest, study 6 both investigated the indicated harvesting times and modified the harvesting method to include TrypLE. However, the harvested viral production in study 6 ranged from $2044 \pm 189$ to $2497 \pm 60$ viral particles/cells and was the lowest among all performed studies. We hypothesized that many viral particles remained in the pellet during the TrypLE- based harvesting process.

To determine the role of the harvesting method in the low yield, we used three different harvesting methods on T-175 flasks in study 7. The viral yields of the T-175 flasks harvested by the mechanical and Lysis buffer A method (10,887 \pm 100 viral particles per cell) were approximately $100 \%$ higher than the viral yield from the Lysis B method (no TrypLE; 4331 viruses/cell) or the Lysis C method (no TrypLE, with washes and benzonase; 5741 viral particles per cell). Comparison of the viral yields from the T-175 flasks harvested by the Lysis B and Lysis C methods raised the possibility that additional washes of the T-175 flask combined with benzonase treatment (Lysis C) augmented the viral yield up to $32 \%$ compared to Lysis B method. The TrypLE and Lysis D methods were not assessed in T-175 flasks. The harvesting methods of ONCOS-infected A549 cells grown in T-175 flasks ranked for viral yields were Lysis A >> Lysis C > Lysis B.

The viral yields from HYPERFlasks harvested with Lysis C (washes, benzonase) and the Lysis D (washes) method resulted in an approximately $45 \%$ lower viral yield (1275 viruses/cell) than the viral yield from HYPERFlask harvested by Lysis buffer C-wash-benzonase method (2374 viruses/cell). Since we hypothesized that many viral particles remained in the pellet during the TrypLE-based harvesting process, we assessed the cell debris pellet from the second $4000 \mathrm{rpm}$ centrifugation for unreleased viral particles during Lysis D harvesting method of HYPERFlask. The pellet was resuspended in $10 \mathrm{~mL}$ of 
Lysis buffer supplemented with benzonase and incubated at $37^{\circ} \mathrm{C}$ for $1 \mathrm{~h}$ (Lysis buffer D). After the lysate was vortexed to ensure a homogenous suspension, it was clarified by $4000 \mathrm{rpm}$ centrifugation. The viral yield released from the pellet was 1275 viruses/cell (pellet 1). These results confirmed that the $4000 \mathrm{rpm}$ pellet had retained about half of the viral productivity from the Lysis D harvesting method. To determine if most of the viral particles had been released during the first treatment of pellet 2, these steps were repeated on the final pellet 2. The viral yield from Pellet 2 was 315 viruses/cell, which indicated that $80 \%$ of the viruses in pellet 1 had been released into the supernatant by the treatment. Taken together, the harvesting methods used for the HYPERFlasks were ranked by viral productivity as follows: Lysis A > Lysis C > TrypLE > Lysis D (Tables 1 and 2).

\subsection{Viral Productivity Summary}

The viral production conditions in both T-175 flasks and HYPERFlasks included A549 cells that were seeded at 15,000 cells $/ \mathrm{cm}^{2}$ and grown to 220,000 cells $/ \mathrm{cm}^{2}$ (approximately $80 \%$ confluent), ONCOS-401 infection at $30 \mathrm{MOI}$, and an incubation period of $66 \mathrm{~h}$. The Lysis A harvesting method provided the highest viral yield from both T-175 flasks (10,887 \pm 100 infectious viral particles/cell) and HYPERFlasks (mean 14,559 \pm 802 infectious viral particles/cell).

\subsection{Glucose and Lactate Measurements}

Glucose and lactate measurements showed stable and comparable conditions for cell growth among flasks represented in each study. The lactate measurements ranged from $88.0 \%$ to $106.8 \%$ of control. The mean glucose measurements ranged from $94.4 \%$ to $106 \%$ of control values. These values indicated that the A549 cell cultures, regardless of infection, were not limited by low glucose levels nor by excess lactate levels.

\section{Discussion}

Common challenges for manufacturing clinical grade oncolytic adenoviruses include the optimization of growth conditions (e.g., cell line, media, and vessel), viral productivity, and initial yields; scalable purification strategies; and formulations that provide long-term stability [11]. Safety considerations during production of clinical viral seed stocks or clinical viral product require a host cell line that minimizes or eliminates the possibility of recombination with host cell integrated Ad E1A sequences that can generate wildtype E1A-driven adenoviruses. The recombined wildtype E1A-driven adenoviruses often have a growth advantage during production of clinical grade viruses and expand to a higher percentage of the viral yield with each passage. As contaminating wildtype E1A-driven viruses can replicate in healthy cells rather than being restricted to growth in cancer cells, the contaminating wildtype E1A-driven viruses may change the specificity of the administered viral product in vivo. On review, HEK293 cells are often used for adenovirus research and production of replication-defective adenoviral vectors as they contain and express the integrated E1A genes [33]. However, ONCOS-401 does not need exogenous E1A to grow in human tumor cells [32]. Thus, the use of HEK293 cells during production of clinical grade ONCOS-401 carries the potential unnecessary risk of generation of wild type E1A-driven adenovirus contamination [11]. To avoid this safety issue, we chose to use the A549 cell line, which is suitable for adenovirus production of replicating adenovirus vectors [34] (like ONCOS-401) that do not require complementation of the $E 1 A$ genes from the host cell.

The conditions that led to the highest ONCOS-401 production in this series were A549 cells grown to 220,000 cells $/ \mathrm{cm}^{2}$, ONCOS-401 infection at $30 \mathrm{MOI}$, and an incubation period of $66 \mathrm{~h}$. The Lysis A harvesting method provided the highest viral yield from both T-175 $\left(175 \mathrm{~cm}^{2}, 10,887 \pm 100\right.$ infectious viral particles/cell) and HYPERFlasks (1720 $\mathrm{cm}^{2}$; mean 14,559 \pm 802 infectious viral particles/cell). These results are substantially higher than the yields in two bioreactors that had grown A549 cells on microcarrier beads and infected with Onco-Ad5 at MOI $=10$ [34]. After $72 \mathrm{~h}$, the two bioreactors had generated $630 \pm 310$ infectious particles (ip)/ cell and $260 \pm 50$ ip/cell, which Souza et al. [34] reported as similar to previous reports [35,36]. The viral productivity of these two bioreactors [34] was routinely 
4 to 10 times lower and up to 20- to 50-fold lower than the results reported here. However, the different assays used to measure infectious viral particles (TCID50 [34] and ICC [20]) may contribute to the different reported viral productivities.

Lesch et al. [37] reported that after HEK293 cells reached 70-80\% confluency, they infected with wildtype Ad5 as a model for optimization of viral productivity from bioreactors. The A549 cell density in these studies were infected at similar confluency (approx. 80\%) but the actual number of A549 cells was higher $\left(220,000\right.$ cells $\left./ \mathrm{cm}^{2}\right)$ than the number of HEK293 reported by Lesch et al. $(173,000$ HEK293 cells $/ \mathrm{cm}^{2}$ ). Lesch et al. reported [37] that the total yield of wildtype Ad5 (MOI 200) in HEK293 cells harvested by Lysis buffer was $7.3 \times 10^{13}$ viral particles in an iCell bioreactor with a surface area of $7362 \mathrm{~cm}^{2}$ or $9.9 \times 109$ viral particles $/ \mathrm{cm}^{2}$. Their different harvesting methods yielded viral productivity that ranged from $1.6 \times 10^{9} \mathrm{vp} / \mathrm{cm}^{2}$ to $9.9 \times 10^{9}$ viral particles $/ \mathrm{cm}^{2}$. In comparison, the ONCOS-401 infected A549 cells grown in HYPERFlasks and T-175 flasks here had produced up to $1.75 \times 10^{9} \pm 0.08$ and $2.12 \times 10^{9} \pm 0.2$ infectious particles of ONCOS-401 per $\mathrm{cm}^{2}$ of surface area, respectively. Although the detection of anti-hexon-stained cells by DAB in our ICC method [20] may be less sensitive than detection by FACS [37], wildtype Ad probably also shows greater replicative ability in HEK293 cells, which express more E1A than ONCOS-401 shows in A549.

The harvesting methods also can have a major impact on viral yield. The Lysis A harvesting method utilized benzonase, which is widely used to cleave DNA and RNA and support release of viruses [35,38]. Viral productivity of ONCOS-401 infected A549 cells (MOI $=10,66 \mathrm{~h}$ incubation) grown in T-175 flasks and harvested with Lysis A buffer method was $6682 \pm 300$ and $8538 \pm 248$ infectious viral particles/cell. A higher inoculum of MOI 30 increased viral productivity by $28 \%$ to $63 \%$, providing 10,887 \pm 100 infectious viral particles/cell. To further investigate harvesting methods, ONCOS-401 infected A549 cells (MOI = 10, $66 \mathrm{~h}$ incubation) were grown in T-175 flasks and harvested by the Lysis B or C methods. The viral productivity from flasks harvested by Lysis B or C were 4331 and 5741 infectious viral particles/cell, respectively. In comparison, use of the Lysis A harvesting method provided viral productivity of 10,887 \pm 100 infectious viral particles / cell which is $152 \%$ and $89 \%$ greater than the yield with the Lysis B and Lysis C methods, respectively. Similar to the T-175 viral yields, the ONCOS-401-infected A549 cells (MOI 30) grown in HYPERFlasks (66 h incubation) and harvested by the Lysis A buffer method yielded the highest viral productivity: mean 14,559 \pm 802 infectious viral particles/cell. In comparison, the TrypLE harvesting method of ONCOS-401-infected A549 cells (MOI 30) grown in HYPERFlasks for $66 \mathrm{~h}$ yielded a much lower viral productivity: $2044 \pm 189$ infectious viral particles/cell. Taken together, our results support the continued usage of the Lysis A harvesting method with benzonase, in agreement with $[11,30,35,38]$. However, efficient methods for viral purification that removes benzonase may be necessary.

The limitations of this study include four points to consider. First, these optimal growth conditions for A549 may need to be modified for other cell lines and other recombinant Ad that do not utilize the same Ad5/3 fiber knob and thus do not share receptors. Kawakami et al. showed that incorporation of the Ad5/3 fiber knob increased viral replication compared with its Ad5 construct [39]. Second, these optimal MOI and harvesting times may vary for other oncolytic adenoviruses, even if they carry the chimeric Ad5/3 fiber knob. For example, the expression of a different transgene by the oncolytic adenovirus, a different mutation of E1A, or a different promoter driving expression of the mutated E1A protein may modify the kinetics of viral replication [40]. In contrast, Doloff et al. showed that Ad5-hTERT-E1A driven oncolytic adenovirus replicated less efficiently than its Ad5 counterpart, ONYX-015 [40]. Diaconu previously reported the initial characterization of ONCOS-401 virus, comparing its cell cytotoxicity to the Ad5/3-hTERT-E1A virus, i.e., without the hCD40L in the E3 region [23]. They showed that the Ad5/3hTERT-E1A virus had much greater cell cytotoxicity activity at $48 \mathrm{~h}$ than ONCOS-401 [32], which is consistent with the later harvesting times of ONCOS-401 observed here. Third, oncolytic viruses may vary in their lytic ability against the host cell line and may necessitate including viral particles from the initial harvest supernatant, as done in the Lysis A harvesting method but not in the TrypLE, Lysis B, C, and D harvesting methods described here. 
Ease of downstream purification steps may be dependent on the volumes obtained during these initial steps; some harvesting methods allow adjustment of the volume for resuspension of harvested infected cells such as the TrypLE, Lysis B, Lysis C-wash, Lysis buffer D-benzonase methods described here. In addition, initial concentration of the oncolytic adenovirus from large initial volumes that include washes may be enhanced by binding to and elution from a column containing an engineered dual-receptor protein [41]. Fourth, although additional adjustments may be needed to optimize yields in vertical wheel bioreactors [34], optimization of many of the presented parameters, as well as key hydrodynamic parameters, can aid in elucidation of the most effective conditions for non-planar bioreactors.

Despite these limitations, this stepwise process of identification of optimal conditions of cell growth, viral replication, and initial processing may be applicable to the optimization of the manufacturing of other oncolytic adenoviruses, whether they are used as single agents $[9,11,42-44]$ or in combination therapies $[3,6,20,45,46]$.

\section{Materials and Methods}

Studies were focused on optimization of the following parameters: cell density (determined previously), multiplicity of infection (MOI) of inoculum of ONCOS-401 and harvesting time (time post infection). An additional aim was to adjust conditions and technical aspects of virus harvesting to maximize the productivity in HYPERFlasks.

\subsection{Cells}

A549 cells were grown in Optipro SFM (Gibco, \#12309-019) supplemented with 1\% fetal bovine serum (FBS, Gibco, 10099-141) and $4 \mathrm{mM}$ Glutamax (Gibco, \#35050-038) at $37{ }^{\circ} \mathrm{C}$ in $5 \% \mathrm{CO}_{2}$ in humidified air. Cells were passaged after trypsin treatment with TrypLE (Gibco, \#12563-011). Cells were used at passage 94 or later (WBC Vibalogics) for the described experiments. A549 cells were seeded at 15,000 cells $/ \mathrm{cm}^{2}$ in Corning CellBind T-175 flasks (\#3292) or HYPERFlask (Corning, \#10030) and incubated for $96 \mathrm{~h}$ or $144 \mathrm{~h}$, respectively. Subsequent incubations of cells or viruses were performed at $37^{\circ} \mathrm{C}$ in $5 \% \mathrm{CO}_{2}$ in humidified air unless indicated otherwise.

\subsection{Lactate/Glucose Measurements}

Supernatant samples were collected before infection and at time of harvesting to evaluate growth conditions in flasks. The lactate and glucose concentrations were measured by using the Accutrend and its meter (OT-134), according to the manufacturer's instructions (Roche, Cobas ${ }^{\circledR}$ ).

\subsection{Virus Titration}

Quantitation of infectious viral particles were performed by the previously described immunocytochemistry (ICC) assay [20], (Figure S1). Briefly, infected cells were detected at $24 \mathrm{~h}$ post infection by staining with anti-hexon antibody and detection by DAB. These reagents-anti-Ad hexon, Novus Biologicals, NB600-413; Biotin-SP-conjugated goat anti-mouse IgG, Jackson Immuno-Research 115-065-062-were used. Viral productivity was defined as the total number of harvested viruses (infectious titer) divided by the total number of cells.

\subsection{Cell Counting}

One flask was harvested at the time of infection for quantifying cell counts and determining lactose and glucose concentrations. After collecting the supernatant, the T-175 flask and HYPERFlask were rinsed gently with $50 \mathrm{~mL}$ or $100 \mathrm{~mL}$ of OptiPro (without FBS), respectively. The T-175 flask and HYPERFlask cells were treated with $5 \mathrm{~mL}$ TrypLE or $50 \mathrm{~mL}$ of TrypLE, respectively, for approximately 1-5 min. The efficiency of TrypLE detachment in the HYPERFlasks was assessed visually under a microscope (Evos xl, OT-114). If needed, HYPERFlasks were treated again with TrypLE. 


\subsection{Viral Infection}

The cells were counted by a cell counter (Countess, OT-115), the quantity of ONCOS-401 was calculated for infection of the T-175 or HYPERFlasks. The flasks were incubated $4 \mathrm{~h}$, flasks received $46 \mathrm{~mL}$ of media or $460 \mathrm{~mL}$ media with $1 \%$ FBS and were incubated for the indicated time periods.

\subsection{Harvesting Methods}

The kinetic studies (48-96 h post infection with ONCOS-401) were performed in order to find the most optimal time for virus harvesting and maximizing the viral yield. Trypsinizing was implemented to release any infected cells that remained attached to the vessel at the time of harvesting and further enhance the viral yield.

Two basic methods of harvest were used: Lysis buffer A and TrypLE. Three subsequent methods combined steps from both the Lysis A method and the TrypLE method: Lysis B, Lysis C-wash, and Lysis buffer D-benzonase methods (Table 2).

Studies 1-5 used the Lysis A harvesting method: media samples were collected. Warm $\left(37^{\circ} \mathrm{C}\right)$ chemical lysis buffer supplemented with benzonase (15 U/mL, sigma-Aldrich, E1014-5KU) was added to each T-175 flask $(10 \mathrm{~mL})$ and HYPERFlask $(100 \mathrm{~mL})$. After $1 \mathrm{~h}$ incubation, cells were collected in sterile Falcon tubes and centrifuged at $3000 \mathrm{RPM}$ for $10 \mathrm{~min}$ at $+4{ }^{\circ} \mathrm{C}$. Supernatants were collected and sucrose was added to $5 \%$ into the virus suspension. Viral stocks were stored at $-80{ }^{\circ} \mathrm{C}$.

TrypLE harvesting method: The medium samples and cells were collected. To remove remaining attached cells from the growing surface of the HYPERFlask (viewed via microscope), we added $50 \mathrm{~mL}$ of TrypLE to each HYPERFlask and incubated them for $5 \mathrm{~min}$. HYPERFlasks were tapped firmly 5-10 times to increase cell detachment. Residual cells were washed and collected with $50 \mathrm{~mL}$ of OptiPro media. If indicated, adherent cells before the addition of TrypLE were washed with $100 \mathrm{~mL}$ of OptiPro (without PBS). After cells were detached, the contents of the HYPERFlask were collected (50 mL-Falcon tubes) and centrifuged gently at $1000 \mathrm{RPM}$ for $10 \mathrm{~min}$ at $4{ }^{\circ} \mathrm{C}$ (centrifugation 1 ). After the supernatant was gently removed, the fragile pellet was resuspended into $8-10 \mathrm{~mL}$ of OptiPro without FBS. This solution was used to resuspend the pellets from all centrifuged samples from a given HYPERFlask. The concentrated viral sample was pipetted back and forth until suspension became homogeneous. The samples were frozen in $10 \mathrm{~mL}$ aliquots $\left(15 \mathrm{~mL}\right.$ sterile Falcon tubes) at $-80^{\circ} \mathrm{C}$. Samples were thawed and frozen three times: room temperature water bath (about $15 \mathrm{~min}$ ), vortexed, and returned to -80 ${ }^{\circ} \mathrm{C}$ freezer for at least overnight. After the third thawing and vortexing, the lysate was centrifuged at $4000 \mathrm{rpm}$ for $15 \mathrm{~min}$ at $+4{ }^{\circ} \mathrm{C}$ (pellet 2). The supernatant was collected, and sucrose was added to yield a $5 \%$ solution. Aliquots were stored at $-80^{\circ} \mathrm{C}$.

Lysis B harvesting method followed the TrypLE method, with the following two modifications: no TrypLE was added, and no subsequent hour incubation was performed.

The Lysis C-wash harvesting method followed the Lysis B harvesting method with one wash for T-175 (50 mL OptiPro with no FBS) and two washes of HYPERFlask $(100 \mathrm{~mL})$ as part of viral and cell collection and before centrifugation.

Lysis D-benzonase harvesting method followed the Lysis $C$ harvesting method with three modifications. Cells were washed with media with no FBS; HYPERFlask, $2 \times 100 \mathrm{~mL}$. The pellet collected after first centrifugation was resuspended with $10 \mathrm{~mL}$ lysis buffer supplemented with benzonase $(15 \mathrm{U} / \mathrm{mL})$ and was incubated for $1 \mathrm{~h}$ at $37^{\circ} \mathrm{C}$. Subsequently, viral suspension was mixed by vortexing to ensure a homogeneous suspension.

\subsection{Biostatistics}

The mean number of infected cells per field was determined from evaluation of 30 photographs. The 95\% confidence interval (CI) for ICC was calculated based on the numbers of infected cells per field by using T-Distribution analyses (Student's T Distribution), where SL was the significance level of 0.05 , SIZE was the number of fields of the group (30 photos represents one field) and SD was 
the standard deviation for each field (30 photos). Precision was defined as the percent coefficient of variation $(\% \mathrm{CV})$. We calculated $\% \mathrm{CV}$ by dividing the standard deviation by the mean for a number of replicate determinations. \%CV was calculated based on the numbers of infected cells per field (30 photos/field). Statistical analysis was performed with GraphPad Prism software version 8 (La Jolla, CA, USA). One-way ANOVA (Kruskal-Wallis test \& Dunn's multiple comparisons test) was used to compare groups.

Supplementary Materials: Supplementary materials can be found at http:/ / www.mdpi.com/1422-0067/20/3/ 621/s1. Figure S1 ICC-staining (10x objective).

Author Contributions: Conceptualization, L.K. and A.V.; Data curation, L.K.; Formal analysis, L.K.; Investigation, L.K.; Methodology, L.K. and A.V.; Project administration, L.K. and A.V.; Resources, L.K. and M.G.; Software, L.K. and A.V.; Supervision, L.K. and A.V.; Visualization, L.K.; Writing-review \& editing, L.K., A.-S.W.M., A.V., S.P., M.G., V.C. and M.J.

Funding: Marie Curie Innovative Training Network (ITN) grant, ADVance (FP7-290002) funded by European Commission supported L.K. MINIATURA 2 (ID: 406438) funded by National Science Center supported L.K.

Acknowledgments: The authors thank Katherine Molnar-Kimber, PhD of Kimnar Group LLC for her editorial assistance.

Conflicts of Interest: L.K., A.S.M., A.V., S.P. are employees and/or shareholders in Targovax Oy in Finland and Targovax ASA in Norway. V.C., S.P. are employees and/or shareholders in Valo Therapeutics. A.V. is employee and/or shareholder in Herantis Pharma Plc.

$\begin{array}{ll}\text { Abbreviations } & \\ \text { DAMP } & \text { damage-associated molecular patterns } \\ \text { DSG } & \text { desmoglein } \\ \text { GM-CSF } & \text { granulocyte-macrophage colony-stimulating factor } \\ \text { hTERT } & \text { human telomerase promoter } \\ \text { ICC } & \text { immunocytochemistry assay } \\ \text { i.v. } & \text { intravenously } \\ \text { MOI } & \text { multiplicity of infection } \\ \text { OV } & \text { oncolytic viruses }\end{array}$

\section{References}

1. Kim, M.; Williamson, C.T.; Prudhomme, J.; Bebb, D.G.; Riabowol, K.; Lee, P.W.; Lees-Miller, S.P.; Mori, Y.; Rahman, M.M.; McFadden, G.; et al. The viral tropism of two distinct oncolytic viruses, reovirus and myxoma virus, is modulated by cellular tumor suppressor gene status. Oncogene 2010, 29, 3990-3996. [CrossRef]

2. Kuryk, L.; Wieczorek, M.; Diedrich, S.; Boettcher, S.A.; Witek, A.; Litwinska, B. Genetic analysis of poliovirus strains isolated from sewage in Poland. J. Med. Virol. 2014, 86, 1243-1248. [CrossRef]

3. Kuryk, L. Strategies to Enhance Efficacy of Oncolytic Virotherapy. Ph.D. Dissertation, University of Helsinki, Helsinki, Finland, 2016.

4. Loskog, A.; Maleka, A.; Mangsbo, S.; Svensson, E.; Lundberg, C.; Nilsson, A.; Krause, J.; Agnarsdottir, M.; Sundin, A.; Ahlstrom, H.; et al. Immunostimulatory AdCD40L gene therapy combined with low-dose cyclophosphamide in metastatic melanoma patients. Br. J. Cancer 2016, 114, 872-880. [CrossRef]

5. $\quad$ Lang, F.F.; Conrad, C.; Gomez-Manzano, C.; Yung, W.K.A.; Sawaya, R.; Weinberg, J.S.; Prabhu, S.S.; Rao, G.; Fuller, G.N.; Aldape, K.D.; et al. Phase I Study of DNX-2401 (Delta-24-RGD) Oncolytic Adenovirus: Replication and Immunotherapeutic Effects in Recurrent Malignant Glioma. J. Clin. Oncol. 2018, 36, 1419-1427. [CrossRef]

6. Bommareddy, P.K.; Shettigar, M.; Kaufman, H.L. Integrating oncolytic viruses in combination cancer immunotherapy. Nat. Rev. Immunol. 2018. [CrossRef]

7. Kaufman, H.L.; Kohlhapp, F.J.; Zloza, A. Oncolytic viruses: A new class of immunotherapy drugs. Nat. Rev. Drug Discov. 2015, 14, 642-662. [CrossRef]

8. Rosewell Shaw, A.; Suzuki, M. Recent advances in oncolytic adenovirus therapies for cancer. Curr. Opin. Virol. 2016, 21, 9-15. [CrossRef] 
9. Garofalo, M.; Iovine, B.; Kuryk, L.; Capasso, C.; Hirvinen, M.; Vitale, A.; Yliperttula, M.; Bevilacqua, M.A.; Cerullo, V. Oncolytic Adenovirus Loaded with L-carnosine as Novel Strategy to Enhance the Antitumor Activity. Mol. Cancer Ther. 2016, 15, 651-660. [CrossRef]

10. Kuryk, L.; Møller, A.-S.W.; Garofalo, M.; Cerullo, V.; Pesonen, S.; Alemany, R.; Jaderberg, M. Antitumor-specific T-cell responses induced by oncolytic adenovirus ONCOS-102 (AdV5/3-D24-GM-CSF) in peritoneal mesothelioma mouse model. J. Med. Virol. 2018, 90, 1669-1673. [CrossRef]

11. Ungerechts, G.; Bossow, S.; Leuchs, B.; Holm, P.S.; Rommelaere, J.; Coffey, M.; Coffin, R.; Bell, J.; Nettelbeck, D.M. Moving oncolytic viruses into the clinic: Clinical-grade production, purification, and characterization of diverse oncolytic viruses. Mol. Ther. Methods Clin. Dev. 2016, 3, 16018. [CrossRef]

12. Capasso, C.; Magarkar, A.; Cervera-Carascon, V.; Fusciello, M.; Feola, S.; Muller, M.; Garofalo, M.; Kuryk, L.; Tahtinen, S.; Pastore, L.; et al. A novel in silico framework to improve MHC-I epitopes and break the tolerance to melanoma. Oncoimmunology 2017, 6, e1319028. [CrossRef]

13. Capasso, C.; Hirvinen, M.; Garofalo, M.; Romaniuk, D.; Kuryk, L.; Sarvela, T.; Vitale, A.; Antopolsky, M.; Magarkar, A.; Viitala, T.; et al. Oncolytic adenoviruses coated with MHC-I tumor epitopes increase the antitumor immunity and efficacy against melanoma. Oncoimmunology 2015, 5, e1105429. [CrossRef]

14. Garofalo, M.; Saari, H.; Somersalo, P.; Crescenti, D.; Kuryk, L.; Aksela, L.; Capasso, C.; Madetoja, M.; Koskinen, K.; Oksanen, T.; et al. Antitumor effect of oncolytic virus and paclitaxel encapsulated in extracellular vesicles for lung cancer treatment. J. Control. Release Off. J. Control. Release Soc. 2018, 283, 223-234. [CrossRef]

15. Lipiec, A.; Kuryk, L. Onkolityczne Wektory Wirusowe w Immunoterapii Nowotworów; Immunoterapia, Wydawnictwo Lekarskie, PZWL: Warszawa, Poland, 2018.

16. Kuryk, L.; Møller, A.-S.W.; Jaderberg, M. Combination of immunogenic oncolytic adenovirus ONCOS-102 with anti-PD-1 pembrolizumab exhibits synergistic antitumor effect in humanized A2058 melanoma huNOG mouse model. Oncoimmunology 2018, 1-11. [CrossRef]

17. Garofalo, M.; Villa, A.; Rizzi, N.; Kuryk, L.; Mazzaferro, V.; Ciana, P. Systemic Administration and Targeted Delivery of Immunogenic Oncolytic Adenovirus Encapsulated in Extracellular Vesicles for Cancer Therapies. Viruses 2018, 10, 558. [CrossRef]

18. Garofalo, M.; Villa, A.; Rizzi, N.; Kuryk, L.; Rinner, B.; Cerullo, V.; Yliperttula, M.; Mazzaferro, V.; Ciana, P. Extracellular vesicles enhance the targeted delivery of immunogenic oncolytic adenovirus and paclitaxel in immunocompetent mice. J. Control. Release 2018. [CrossRef]

19. Bramante, S.; Kaufmann, J.K.; Veckman, V.; Liikanen, I.; Nettelbeck, D.M.; Hemminki, O.; Vassilev, L.; Cerullo, V.; Oksanen, M.; Heiskanen, R.; et al. Treatment of melanoma with a serotype 5/3 chimeric oncolytic adenovirus coding for GM-CSF: Results in vitro, in rodents and in humans. Int. J. Cancer 2015, 137, 1775-1783. [CrossRef]

20. Kuryk, L.; Haavisto, E.; Garofalo, M.; Capasso, C.; Hirvinen, M.; Pesonen, S.; Ranki, T.; Vassilev, L.; Cerullo, V. Synergistic anti-tumor efficacy of immunogenic adenovirus ONCOS-102 (Ad5/3-D24-GM-CSF) and standard of care chemotherapy in preclinical mesothelioma model. Int. J. Cancer 2016, 139, 1883-1893. [CrossRef]

21. Malmstrom, P.U.; Loskog, A.S.; Lindqvist, C.A.; Mangsbo, S.M.; Fransson, M.; Wanders, A.; Gardmark, T.; Totterman, T.H. AdCD40L immunogene therapy for bladder carcinoma-The first phase I/IIa trial. Clin. Cancer Res. 2010, 16, 3279-3287. [CrossRef]

22. Pesonen, S.; Diaconu, I.; Kangasniemi, L.; Ranki, T.; Kanerva, A.; Pesonen, S.K.; Gerdemann, U.; Leen, A.M.; Kairemo, K.; Oksanen, M.; et al. Oncolytic immunotherapy of advanced solid tumors with a CD40L-expressing replicating adenovirus: Assessment of safety and immunologic responses in patients. Cancer Res. 2012, 72, 1621-1631. [CrossRef]

23. Diaconu, I.; Cerullo, V.; Hirvinen, M.L.; Escutenaire, S.; Ugolini, M.; Pesonen, S.K.; Bramante, S.; Parviainen, S.; Kanerva, A.; Loskog, A.S.; et al. Immune response is an important aspect of the antitumor effect produced by a CD40L-encoding oncolytic adenovirus. Cancer Res. 2012, 72, 2327-2338. [CrossRef] [PubMed]

24. Schiza, A.; Wenthe, J.; Mangsbo, S.; Eriksson, E.; Nilsson, A.; Totterman, T.H.; Loskog, A.; Ullenhag, G. Adenovirus-mediated CD40L gene transfer increases Teffector/Tregulatory cell ratio and upregulates death receptors in metastatic melanoma patients. J. Transl. Med. 2017, 15, 79. [CrossRef] [PubMed]

25. Kuryk, L.; Moller, A.W.; Jaderberg, M. Quantification and functional evaluation of CD40L production from the adenovirus vector ONCOS-401. Cancer Gene Ther. 2018. [CrossRef] 
26. Choi, I.K.; Lee, J.S.; Zhang, S.N.; Park, J.; Sonn, C.H.; Lee, K.M.; Yun, C.O. Oncolytic adenovirus co-expressing IL-12 and IL-18 improves tumor-specific immunity via differentiation of T cells expressing IL-12Rbeta2 or IL-18Ralpha. Gene Ther. 2011, 18, 898-909. [CrossRef]

27. Ranki, T.; Pesonen, S.; Hemminki, A.; Partanen, K.; Kairemo, K.; Alanko, T.; Lundin, J.; Linder, N.; Turkki, R.; Ristimaki, A.; et al. Phase I study with ONCOS-102 for the treatment of solid tumors-An evaluation of clinical response and exploratory analyses of immune markers. J. Immunother. Cancer 2016, 4, 17. [CrossRef] [PubMed]

28. Wang, H.; Li, Z.Y.; Liu, Y.; Persson, J.; Beyer, I.; Moller, T.; Koyuncu, D.; Drescher, M.R.; Strauss, R.; Zhang, X.B.; et al. Desmoglein 2 is a receptor for adenovirus serotypes 3, 7, 11 and 14. Nat. Med. 2011, 17, 96-104. [CrossRef] [PubMed]

29. Koyama-Nasu, R.; Takahashi, R.; Yanagida, S.; Nasu-Nishimura, Y.; Oyama, M.; Kozuka-Hata, H.; Haruta, R.; Manabe, E.; Hoshino-Okubo, A.; Omi, H.; et al. The cancer stem cell marker CD133 interacts with plakoglobin and controls desmoglein-2 protein levels. PLOS ONE 2013, 8, e53710. [CrossRef] [PubMed]

30. Ausubel, L.J.; Meseck, M.; Derecho, I.; Lopez, P.; Knoblauch, C.; McMahon, R.; Anderson, J.; Dunphy, N.; Quezada, V.; Khan, R.; et al. Current good manufacturing practice production of an oncolytic recombinant vesicular stomatitis viral vector for cancer treatment. Hum. Gene Ther. 2011, 22, 489-497. [CrossRef]

31. Hendrickx, R.; Stichling, N.; Koelen, J.; Kuryk, L.; Lipiec, A.; Greber, U.F. Innate immunity to adenovirus. Hum. Gene Ther. 2014, 25, 265-284. [CrossRef]

32. Diaconu, I.; Cerullo, V.; Escutenaire, S.; Kanerva, A.; Bauerschmitz, G.J.; Hernandez-Alcoceba, R.; Pesonen, S.; Hemminki, A. Human adenovirus replication in immunocompetent Syrian hamsters can be attenuated with chlorpromazine or cidofovir. J. Gene Med. 2010, 12, 435-445. [CrossRef]

33. Kovesdi, I.; Hedley, S.J. Adenoviral Producer Cells. Viruses 2010, 2, 1681-1703. [CrossRef] [PubMed]

34. Sousa, M.F.; Silva, M.M.; Giroux, D.; Hashimura, Y.; Wesselschmidt, R.; Lee, B.; Roldao, A.; Carrondo, M.J.; Alves, P.M.; Serra, M. Production of oncolytic adenovirus and human mesenchymal stem cells in a single-use, Vertical-Wheel bioreactor system: Impact of bioreactor design on performance of microcarrier-based cell culture processes. Biotechnol. Prog. 2015, 31, 1600-1612. [CrossRef] [PubMed]

35. Dormond, E.; Kamen, A.A. Manufacturing of adenovirus vectors: Production and purification of helper dependent adenovirus. Methods Mol. Biol. 2011, 737, 139-156. [CrossRef] [PubMed]

36. Vellinga, J.; Smith, J.P.; Lipiec, A.; Majhen, D.; Lemckert, A.; van Ooij, M.; Ives, P.; Yallop, C.; Custers, J.; Havenga, M. Challenges in manufacturing adenoviral vectors for global vaccine product deployment. Hum. Gene Ther. 2014, 25, 318-327. [CrossRef] [PubMed]

37. Lesch, H.P.; Heikkila, K.M.; Lipponen, E.M.; Valonen, P.; Muller, A.; Rasanen, E.; Tuunanen, T.; Hassinen, M.M.; Parker, N.; Karhinen, M.; et al. Process Development of Adenoviral Vector Production in Fixed Bed Bioreactor: From Bench to Commercial Scale. Hum. Gene Ther. 2015, 26, 560-571. [CrossRef] [PubMed]

38. Eglon, M.N.; Duffy, A.M.; O’Brien, T.; Strappe, P.M. Purification of adenoviral vectors by combined anion exchange and gel filtration chromatography. J. Gene Med. 2009, 11, 978-989. [CrossRef] [PubMed]

39. Kawakami, Y.; Li, H.; Lam, J.; Krasnykh, V.; Curiel, D.; Blackwell, J. Substitution of the Adenovirus Serotype 5 Knob with a Serotype 3 Knob Enhances Multiple Steps in Virus Replication. Cancer Res. 2003, 63.

40. Doloff, J.C.; Waxman, D.J.; Jounaidi, Y. Human telomerase reverse transcriptase promoter-driven oncolytic adenovirus with E1B-19 kDa and E1B-55 kDa gene deletions. Hum. Gene Ther. 2008, 19, 1383-1400. [CrossRef]

41. Wu, Q.; Liu, W.; Xu, B.; Zhang, X.; Xia, X.; Sun, H. Single-step concentration and purification of adenoviruses by coxsackievirus-adenovirus receptor-binding capture and elastin-like polypeptide-mediated precipitation. Arch. Virol. 2016, 161, 279-287. [CrossRef]

42. Kaliberov, S.A.; Kaliberova, L.N.; Buchsbaum, D.J.; Curiel, D.T. Experimental virotherapy of chemoresistant pancreatic carcinoma using infectivity-enhanced fiber-mosaic oncolytic adenovirus. Cancer Gene Ther. 2014, 21, 264-274. [CrossRef]

43. Kawashita, Y.; Deb, N.J.; Garg, M.K.; Kabarriti, R.; Fan, Z.; Alfieri, A.A.; Roy-Chowdhury, J.; Guha, C. An autologous in situ tumor vaccination approach for hepatocellular carcinoma. 2. Tumor-specific immunity and cure after radio-inducible suicide gene therapy and systemic CD40-ligand and Flt3-ligand gene therapy in an orthotopic tumor model. Radiat. Res. 2014, 182, 201-210. [CrossRef] [PubMed] 
44. Kuryk, L.; Vassilev, L.; Ranki, T.; Hemminki, A.; Karioja-Kallio, A.; Levalampi, O.; Vuolanto, A.; Cerullo, V.; Pesonen, S. Toxicological and bio-distribution profile of a GM-CSF-expressing, double-targeted, chimeric oncolytic adenovirus ONCOS-102-Support for clinical studies on advanced cancer treatment. PLoS ONE 2017, 12, e0182715. [CrossRef] [PubMed]

45. Hirvinen, M.; Capasso, C.; Guse, K.; Garofalo, M.; Vitale, A.; Ahonen, M.; Kuryk, L.; Vaha-Koskela, M.; Hemminki, A.; Fortino, V.; et al. Expression of DAI by an oncolytic vaccinia virus boosts the immunogenicity of the virus and enhances antitumor immunity. Mol. Ther. Oncolytics 2016, 3, 16002. [CrossRef]

46. Wing, A.; Fajardo, C.A.; Posey, A.D., Jr.; Shaw, C.; Da, T.; Young, R.M.; Alemany, R.; June, C.H.; Guedan, S. Improving CART-Cell Therapy of Solid Tumors with Oncolytic Virus-Driven Production of a Bispecific T-cell Engager. Cancer Immunol. Res. 2018, 6, 605-616. [CrossRef] [PubMed]

2019 by the authors. Licensee MDPI, Basel, Switzerland. This article is an open access article distributed under the terms and conditions of the Creative Commons Attribution (CC BY) license (http:// creativecommons.org/licenses/by/4.0/). 